\title{
ILUSTRASI TENTANG REENGINEERING HUMAN RESOURCES (Kajian Buku: \\ Lyle Spencer, Reengineering Human Resourcess)
}

\author{
Oleh: Zubaidah Al-Bugis*
}

\section{Pendahuluan}

Maksud dari Reengineering Human Resources biasanya adalah suatu MIS (Management Information System) yang dikaitkan dengan kemajuan teknologi perangkat digital yang dalam aplikasinya dapat menjangkau semua proscs kebutuhan Manusia.

Prof. Michael Hammer menyusun suatu formulasi scbagai bcrikut: Asal mula timbulnya perkembangan akal pcrubahan dalam pemikiran dalam proses bisnis menyebabkan kemajuan aplikasi yang sangat dragmatis yang berdampak makin kritis, penampilan atau kinerja yang sangat maju seperti dalam biaya, mutu, servis (pelayanan) dalam kecepatan (p. 32) dengan pemakaian teknologi informasi, suatu teknologi serba bisa dan sesudah perusahan-perusahan memanfaatkan teknologi dalam proses bisnisnya (p. 83).

Penggunaan teknologi berarti telah dimulai dari awal penggabungan antara Reengineering sumber daya manusia dengan teknologi, sebagai inti dari pemanfaatan teknologi, sebagai inti dari pemanfaatan teknologi dalam cara berpikir yang berdampak dalam pelaksanaan kegiatan yang kita kerjakan akan lebih cepat, tepat, akurat, efisien dengan jangkauan hubungan kescmua aspek kebutuhan Manusia.

Reengineering dapat ditinjau dalam skala Macro dan Micro (secara rinci dapat dilihat pada h. 163-182). Macro Reengineering berarti langkah pertama sudah memanfaatkan teknologi dalam berpikir, melaksanakan pekcrjaan, produk kerja dan pelayanan perusahaan sudah memakai teknologi, sehingga prinsip (DIY) "do it yourself' sudah ketinggalan.

Secara garis besar perubahan management sumberdaya Manusia adalah mulainya pemanfaatan teknologi khususnya perangkat digital dalam proses manajemen sumber daya manusia. Dalam buku "Reengineering sumberdaya manusia " disebutkan tentang :

\footnotetext{
* Penulis adalah dosen tetap pada Jurusan Tarbiyah STAIN Manado, menyelesaikan program S2 pada Pascasrajana Universitas Sam Ratulangi Manado pada program studi Pengelolaan Sumbcrdaya Pembangunan.
} 
1. Pengertian praktis dari reengineering sumberdaya manusia adalah : perubahan drastis dari teknologi integrated (diintegrasikan) dengan management information system sumberdaya manusia, yang telah bersifat mendunia dalam hubungan, dan semua kebutuhan manusia dapat dibaca pada monitor, baik pelayanan yang dibutuhkan maupun staffing.

2. Ilustrasi untuk reengineering adalah analisa bagan alir kerja, biaya/dana analisa kemajuan dapat dilaksanakan dengan perangkat canggih "software" berupa program-program khusus.

3. Pemanfaatan untuk masyarakat dari reengineering adalah hasil kerja dari sumbcr daya Manusia secara professional harus menggunakan peralatan canggih dan memanfaatkan teknologi.

4. Bagaimana merencanakan dan melaksanakan sumberdaya Manusia dengan cara reengineering yang berdaya guna untuk para staf dan fungsi bisnis adalah mempersingkat proses perencanaan dan pelaksanaan untuk kecepatan waktu putaran dalam perusahaan dan mcmpercepat hubungan kebutuhan dengan pemakai jasa.

5. Bagaimana menghitung pengurangan biaya dalam investasi peralatan, sistem pembangunan pelatihan karyawan dalam Reengineering. Reengineering itu sendiri berarti pemanfaatan teknologi dalam sumber daya Manusia.

Secara singkat "Reengineering sumber daya Manusia" adalah: bahwa hampir 80\% kegiatan manajemen sumber daya Manusia dibantu dengan peralatan canggih digital bcrupa PC dan audio system. Proses yang dapat dilayani manajemen sumber daya manusia dalam reengineering process adalah staffng, pelatihan, proses pembangunan, perkembangan kemajuan perusahaan, segala kegiatan, pcmecahan masalah, pclayanan dan lain-lain dapat dipecahkan secara cepat, efisicn dan ekonomis sehingga untuk monyusun strategi baik untuk "Balance Sheet" maupun Profit anda Loss Statement " untuk suatu strategi mudah dibuat.

\section{Ringkasan}

Dalam menyusun ringkasan dari reengineering sumberdaya manusia dibagi dalam enam aspek, yaitu:

1) Arti dan definisi Reengineering sumberdaya Manusia

2) Apa yang dapat dikerjakan dengan Reengineering sumberdaya manusia

3) Proses Reengineering sumberdaya manusla

4) Manfaat dari Reengineering sumberdaya manuS1a 
5) Alat-alat digital untuk Reengineering sumberdaya manusia dan kemajuan teknologi

6) Masa depan Reengineering sumberdaya manusra.

\section{Arti dan Definisi Reengineering Sumberdaya Manusia}

Istilah reengineering yang terdiri dari dua kata, yaitu: Re yang bcrarti kembali, dan kata engineering $(n)$ yang merupakan istilah teknis yang lazim digunakan dalam bidang disiplin ilmu teknologi untuk pengcrtian kerekayakaan. Jadi reengineering dapat diartikan sebagai rekayasa ulang. Perkembangan selanjutnya penggunaan istilah reengineering ini bergcser dari pengertian teknis kepada pengcrtian yang lebih luas, namun tidak terlepas dari bingkai teknis seperti semula.

Berdasarkan studi literature, ditemukan bahwa Hammer (1990), dipandang sebagai orang pertama yang mulai mempcrkenalkan istilah reengineering ini dalam bukunya yang berjudul: Reengineering Work: Don 't Automate, Obliterate, Ilanard Bussiness Review; JulyAugust. Kemudian disusul Hammer \& Champy (1993) dalam bukunya reengineering the Corporation. York York: Harper Collings. Ide dari para penulis yang telah kita sebutkan diatas ternyata banyak mempengaruhi ide Lyle M. Spencer, $J r$ dalam tulisannya yang berjudul Reengineering Human Resources. Reengineering sumberdaya Manusia dengan mclibatkan teknologi informasi kedalam proses bisnis merupakan suatu terobosan baru, dimana hampir selama 200 tahun proses bisnis bcrlangsung dalam kondisi yang in-efisiensi, biaya produksi yang makin tinggi, proses kerja yang makin kompleks serta pelayanan yang begitu lamban.

Rekayasa ulang (Reengineering HR) sumberdaya manusia merupakan simplifikasi proses bisnis. untuk memenuhi kebutuhan pelanggan terhadap mutu produk dan pelayanan, fleksibilitas dan dengan biaya yang murah. Dalam hal inilah diperlukan Reengineering sumberdaya Manusia untuk meredesign, bagaimana proses bisnis itu dirancang dan bagaimana organisasi bisnis itu dibentuk.

Rekayasa ulang adalah proses berpikir kembali (rethinking), proscs perencanaan kembali (redesign) secara mendasar untuk memperoleh perbaikan (improvement) yang memuaskan (satisfaction) atas kinerja (performance) perusahaan yang mencakup cost, quality, delivery, service dan speed dengan pengukuran yang teliti dan kontemporer.

Reengineering Human Resources mengharuskan kita untuk berkonsentrasi pada proses dan strategi yang berorientasi pada transformasi. Transformasi meliputi reframing 
(mimbingkai ulang dengan visi yang baru), restructuring (perbaikan struktur yang baru), dan revitalizing (revitalisasi), dan renewing (pcmbaharuan kembali).

Reengineering Human Resources untuk pengertian redesign proscs bisnis bertujuan untuk memperoleh keuntungan dari potensi yang sudah dimiliki oleh perusahaan sepeni computer dan teknologi informasi, dimaksudkan untuk perbaikan proses, peningkatan kepuasan total baik pelanggan internal maupun pelanggan eksternal. Contoh IBM Credit, ia segera menata ulang proses bisnis nya dimana permohonan kredit tidak lagi diproses oleh para spesialis tapi cukup oleh Seorang generalis dengan bantuan Sistim computer yang handal. Keuntungan dari proses perampingan kerja terintegrasi antara lain melibatkan sedikit orang, pekerja semakin bertanggung jawab karena terlibat langsung dalam proses serta mudah memantau kinerja dari unit-unit terintegrasi melalui Reengineering Human Resources proses bisnis itu IBM credit mampu menekan dan memperpendek waktu proses dari rata-rata enam hari menjadi empat jam dan menghemat biaya sampai $34 \%$.

Dalam merekayasa ulang proses kerja dibuat menjadi sederhana dengan cara kompresi tanggungiawab perusahaan kepada Intrated Customer Service Representatiom Unit ini menyusun keseluruhan proses dan memberikan pelayanan sebagai titik tunggal kontak dengan pelanggan.

Rekasaya ulang dalam proses diarahkan kepada pcnyederhanaan tugas yang dibebankan kepada pekerja agar mampu memenuhi permintaan konsumen yang begitu kompleks seperti tuntutan mutu produk yang lebih baik, harga yang terjangkau dan ketetapan waktu penyerahan.

Reengineering fase pertama sudah dimulai scjak awal penggabungan antara reengineering sumberdaya Manusia dengan perangkat teknologi sebagai inti titik dari pemanfaatan teknologi dalam metodc berpikir yang berdampak pada pelaksanaan kegiatan yang akan dikerjakan.

Prof. Michael Hammer menyusun suatu formulasi sebagai bcrikut: "asal mula timbulnya perkembangan akal perubahan dalam pemikiran dalam proses bisnis menyebabkan kemajuan aplikasi (penerapan) yang sangat dramatis yang berdampak makin kritis, penampilan (kincrja) yang sangat maju scperti dalam biaya, mutu, service (pelayanan) dan kecepatan. (p. 32) dengan pemakaian teknologi informasi, suatu teknologi serba bisa dengan 
mudah sesudah perusahaan-perusahaan memanfaatkan teknologi dalam proses bisnisnya (p. $83)$.

Penggunaan teknologi berarti telah dimurai dari awal penggabungan antara reengineering sumbcrdaya Manusia dengan teknologi. Sebagai inti dari pemanfaatan teknologi dalam cara berpikir yang berdampak dalam pelaksanaan kegiatan yang kita kerjakan akan lebih cepat, tepat, akurat, efisien dengan jangkauan hubungan kesemua aspek kebutuhan Manusia.

"Reengineering" dapat ditinjau skope "Macro" dan "Micro" (secara rinci dapat dilihat pada h. 163-182). "Macro Reengineering" berarti langkah pertama sudah memanfaatkan teknologi dalam berpikir, melaksanakan pekerjaan, produk kerja dan pelayanan perusahaan sudah memakai teknologi sehingga prinsip (DIY) "do it yourself' sudah ketinggalan.

Bagan alir dari kegiatan "Human Resources" (sumberdaya Manusia) sebagai berikut:

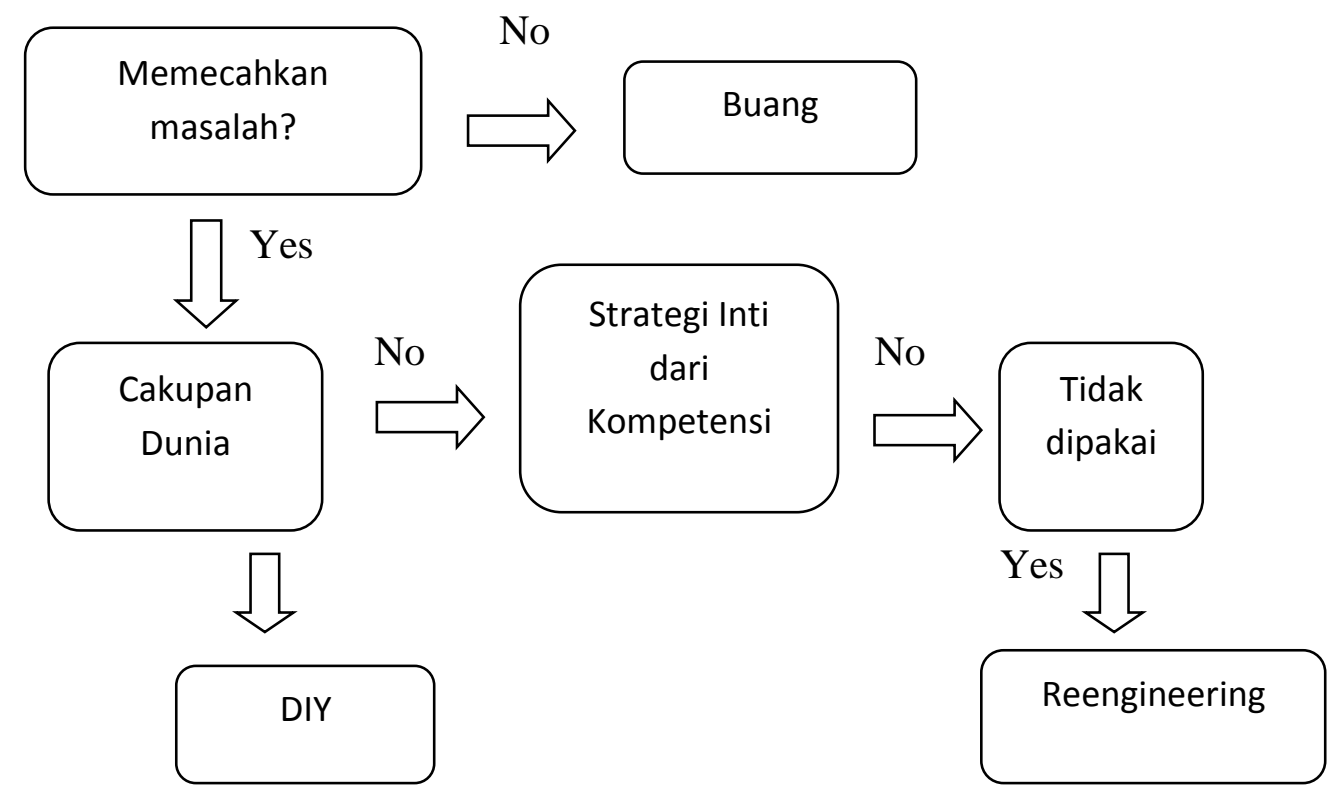

Untuk kelas dunia :

- Dana / biaya

- Perputaran waktu

- Memuaskan pelanggan

Gambar

Bagan alir untuk menyelesaikan pekerjaan versus "DIY" dan Reengineering" 
Secara garis besar perubahan manajemen sumber daya manusia adalah mulainya pemanfaatan teknologi khususnya perangkat digital dalam proses manajeme\&l sumber daya Manusia.

Dalam buku "Reengineering sumber daya Manusia" disebutkan tentang :

1. Pengertian praktis dari reengineering sumber daya Manusia adalah : perubahan drastic dari teknologi informasi integrated (diintegrasikan) dengan management information system sumber daya Manusia, yang telah bersifat mendunia dalam hubungan, dan semua kebutuhan Manusia dapat dibaca pada monitor, baik pelayanan yang dibutuhkan maupun staffing.

2. Ilustrasi untuk Reengineering adalah analisa bagan alir kerja, biaya/dana, analisa kemajuan dapat dilaksanakan dengan perangkat canggih "Software" berupa programprogram khusus.

3. Pemanfaatan untuk masyarakat dari Reengineering adalah hasil kerja dari sumber daya Manusia secara professional harus menggunakan pcralatan canggih dan memanfaatkan teknologi.

4. Bagaimana merencanakan melaksanakan sumbcr daya Manusia dengan cara reengineering yang berdayaguna untuk para staf dan fungsi bisnis adalah mempersingkat proses perencanaan dan pelaksanaan untuk kecepatan waktu putaran dalam perusahan dan mempercepat hubungan kcbutuhan dengan pemakai jasa.

5. Bagaimana menghitung pengurangam' penurunan biaya dalam investasi peralatan, sistem pengembangan, pelatihan karyawan dalam reengineering. Reengineering itu sendiri berarti pemanfaatan teknologi dalam sumber daya Manusia.

Secara singkat"Reengineering sumber daya Manusia" adalah : bahw hampir 80\% kegiatan manajemen sumber daya Manusia dibantu dengan peralatan canggih digital berupa PC dan audio-system.Proses yang dapat dilayani manajemen sumber daya Manusia dalam proses reengineering adalah staffting, pelatihan, proses pembangunan, perkcmbangan kemajuan perusahaan, segala kegiatan, pemecahan masalah, pelayanan, dan Iain-lain dapat dipecahkan secara cepat, efisien, tepat dan ekonomis sehingga untuk menyusun strategi baik untuk "Balance Sheet" maupun "Profit and loss statement " untuk suatu strategi mudah dibuat. 


\section{Apa yang dapat dikerjakan dengan Reengineering suntber daya menusia}

Reengineering berarti memasukkan teknologi ke dalam proses manajemen sumber daya Manusia. Teknologi yang dimaksud adalah peralatan canggih dengan perangkat digital yang berbentuk alat Computation dan secara market disebut komputer.

Komputer dibagi dalam 2 bagian yaitu:

a. Hardware (perangkat keras)

Perangkat fisik terdiri dari keyboard, CPU, monitor, printer.

Perangkat keras ini merupakan alat fisik yang masing-masing mempunyai 3 fungsi yaitu:

- Memberikan input (keyboard)

- Memproses input menjadi output (CPU)

- Menampilkan output hasil proses (monitor/printer)

Di dalam proses, dikumpulkan datadata, baik data input maupun data output (hasil proses) dalam memory berupa perangkat harddisk (yang berada dalam CPU)

Kunci dari kecanggihan digital adalah processor yang diklaim sebagai hasil instal. Kemajuan dari teknologi processor itu dinyatakan dengan versi "Pentium". Saat ini yang dianggap tercanggih adalah Pentium 4 versi 5. Perangkat keras ini dipasaran bisa dinamakan PC (personal computer), desktop, note book, HPU dan lain-lain.

Catatan : Pentium menentukan kecepatan proses dan kapasitas memory sedangkan versi menentukan banyaknya jenis proses yang bisa diakses. Biarpun produknya dengan merek bermacam-macam namun kualitas dari pada processing computer tersebut ditentukan oleh seri Pentium dan versinya.

b. Software (perangkat lunak)

Yang dimaksud dengan perangkat lunak adalah program yang menjalankan CPU berdasarkan proses yang akan diakses. Peran sumber daya Manusia yang paling penting adalah reengineering sumber daya Manusia yaitu menyusun dan merencanakan programprogram sesuai dengan kebutuhan yang diinginkan, sehingga output yang diharapkan sesuai dengan proses digital. Orang yang menyusun program disebut programmer. Di dalam reengineering sumbcr daya Manusia, seorang programmer sangat penting dalam menentukan kelancaran, ketcpatan, efisiensi dan dayaguna. 
Yang dimaksud dengan tekmologi adalah perangkat lunak (software), berarti reengineering sumberdaya Manusia adalah program atau perencanaan dengan memasukan teknologi pada manjemen sumberdaya Manusia. Alat tidak akan bisa bekerja tanpa operator. Dalam hal peran seorang operator hanya menjalankan / mengoperasikan, ia tidak terlalu penting. mengetahui secara rinci tentang perangkat lunak.

Di dalam kemajuan teknologi digital ada istilah reengineering phase II (p. 22). Yang dimaksud dengan phase II adalah reengineering sumber daya Manusia yang dikaitkan dengan kemajuan teknologi perangkat canggih yang digunakan didalam peralatan digital tersebut.

Joe Bloggs dan Auerback dan Fernia's telah membuat suatu peningkatan "versi" di dalam perangkat lunak sehingga hasilnya lebih cepat, tepat dan berdaya guna. Hasil dari peningkatan "'versi" peralatan yang dihasilkan dari hari ke hari sangat pesat kemajuannya schingga dapat lebih berhasil guna untuk peningkatan reengineering sumberdaya manusia.

Sesuai dengan grafik 1.13 dinyatakan bahwa dana untuk masing-masing bagian dałam manajemen sumberdaya Manusia adalah human resources 1\%, administrasi 19\%, penggajian karyawan 5\%, modal 22\%, biaya pemasaran produk 25\% dan materiał $270 / 0$.

Biarpun dana untuk sumberdaya Manusia hanya 1\%, namun demikian keberhasilan suatu perusahaan/organisasi justru sumberdaya Manusia inilah yang hanus ditingkatkan dałam hal ini dengan metode reengineering (p. 26, 27, 28, 29).

\section{Proses Reengineering Sumberdaya Manusia}

Yang dimaksud dengan reengineering sumber daya Manusia adalah memanfaatkan teknologi didalam proses manajemen sumber daya Manusia. Pemanfaatan teknologi berarti sumberdaya Manusia yang dipakai harus dibekali dengan teknologi yang dapat membuat proses yang dilaksanakan menjadi lebih cepat, tepat dan efisien. Perangkat yang dipakai harus mempunyai program software yang dapat melaksanakan pekerjaan yang dimaksud sebagai syarat memajukan sumber daya Manusia. Oknum sumber daya manusia yang dilibatkan di dałam proses reengineering harus dapat menguasai teknologi dałam pembuatan program sesuai kebutuhan manajemen sumber daya Manusia yang hasilnya cepat, tepat dan efisien. Sedangkan, karyawan yang bekerja sebagai operator, harus menguasai pengoperasian secara cepat dan benar.

Di dałam proses reengineering sumber daya Manusia seluruh programprogram computer disusun sesuai dengan kebutuhan sehingga hasilnya cukup optimum. Proses ini melewati pendidikan dan pelatihan dengan kualifikasi yang sudah ditentukan sebelumnya. 
Keuntungan dari proses reengineering sumber daya Manusia adalah .

- penghematan dana personil

- jangkauan lebih luas pengendalian manajemen tidak harus ditempat

- efisiensi lebih tinggi

Apa keuntungan dari segi customer (p. 30) Akibat dari pada reengineering sumber daya Manusia pihak customer diuntungkan 6 item.

- Dari segi waktu

Dengan menajemen reengineering sumber daya Manusia proses waktu limit on time (lebih cepat)

- Tidak terbatas dengan łokasi tertentu Yang dimaksud dengan iłem ini, jangkauan perangkat keras tidak terbatas (internet, email, web / jaringan). Dałam istilah majemen iłem ini disebut "lintas ruang".

- Realitas

Semua pekerjaan, perencanaan dan pelaksanaan dapat dikerjakan up to date, ideał dan akurat.

- Menguntungkan (tanginable)

Karena efisien dałam waktu, efisien dałam jarak, dan realitas, pekerjaan terlaksana, maka dari segi efisicnsi meningkat, berarti "menguntungkan"

- Empaty

Pelayanan dari hasil sangat sangat menarik, karena tepat waktu dan informasi dapat diterima denganjelas tanpa restorsi.

- Jaminan / keterjaminan

Dengan singkatnya waktu yang dibutuhkan dan mudahnya serta ketepatan pelayanan maka manajemen reengineering sumber daya Manusia dapat diberikan "jaminan mułu "(p. 30).

Di samping yang tercatat diatas, dapat memberikan keuntungan "peningkatan kemampuan" (empowerment) memberikan stimulasi (dorongan, baik bagi karyawan internal maupun pengguna jasa, estetis (menariWmenyenangkan). Service (pelayanan) yang diberikan merupakan produk-produk yang estetis (grafiknya berwarna, menarik dan lainlain). Dan terakhir produk ini dapat menyajikan suatu pelayanan yang menarik Contoh pelayanan ATM (mesin pembayar otomatis) (p. 32). Contoh lain OT (otomatic translator) dari EDLIN. 


\section{Manfaat kegunaan dari reengineering sumber daya Manusia}

Manfaat dari reengineering sumber daya Manusia yang dapat ditarik antara lain :

- Dari segi waktu lebih cepat

- Dari segi jarak tidak terbatas (all the world/ lintas dunia)

- Menampung pengarsipan hanya membutuhkan tempat yang kecil (sedikit) untuk memasang jumlah data yang tak terbatas compact disk (cd), hard disk (hd), disket, dan flash memory.

Dengan keuntungan-keuntungan yang dijelaskan diatas, suatu perusahaan / organisasi yang menggunakan system reengineering sumber daya Manusia tidak memerlukan Iemarilemari besar, kotak-kotak arsip yang banyak, namun yang diperlukan hanya kotak data disk yang kecil saja, terkunci dan rahasianya cukup terjamin (p. 38-39).

Di dalam Management Information System (MIS) juga dipengaruhi oleh reengineering system, sebab peran teknologi didalam MIS dapat memberikan kapasitas efisiensi yang cukup tinggi.

Reengineering dalam pengertian ini adalah memakai/menggunakan teknologi informasi sistem yang mampu bekerja dalam kapasitas dan efisiensi yang cukup tinggi. Sebagai contoh antara lain penggunaan peralatan computer dalam sistem LAN / WAN, seperti dalam gambar 2.2, p.42, masih banyak lagi keuntungan yang diberikan oleh reengineering sumber daya Manusia dengan menggunakan digital.

\section{Alat-alat yang ada sesuai kemajuan teknologi yang digunakan untuk manajemen sumber daya manusia}

Alat-alat biasa yang digunakan dalam proses manajemen reengineering human recouces adalah alat-alat :

- Perekam data (personal computer)

- Alat-alat pemprosesan data yaitu PDA (Personal Digital Assistant)

- PDA

Yang dimaksud dengan PDA adalah suatu alat yang dapat dibawa kemana-mana namun mempunyai daya proses sama dengan PC. Biasanya PDA digunakan sebagai organizer para top manajer. 
- Wide Boarding Software (WBS)

adalah alat berupa white board electronic dimana apa yang ditulis pada whiteboard dapat terekam kedalam komputer dan langsung digunakan untuk sarana conference / presentasi.

- $\quad$ PC (Personal Computer)

$P C$ merupakan suatu alat perekam data, penulis dan proses data sesuai program Yang di install ke dalam PC tersebut (p. 38-44). PC ini dihubungkan secara online dengan PC lain untuk kepentingan LAN maupun WAN scperti pada administrasi online dan Bank yang juga dihubungkan dengan A TM.

- ATM (Automatic Teller Machine)

ATM ini adalah alat pengganti teller sebagai pembayar dan pengadministrasian msuk keluamya dana pada rekening Bank untuk keperluan biro-biro perjalanan ATM berupa mesin online service registration yaitu mesin yang mencatat tempat duduk (Seat) pesawat (p. 124,133)

- Main Frame

adalah suatu jenis komputer dengan memory : Mega Byte (MB) dengan daya proses sampai ratusan item (p. 39).

- Desktop PC

adalah komputer berbentuk kotak yang dilekatkan diatas meja. DPC biasanya mempunyai memory yang cukup tinggi sebab bisa diinstall berbagai macam program sekaligus. Contoh Auto CAD, Correl Draw, Printer dan lain-lain (p. 2738, 30, 39 dan 40).

- Laptop

Merupakan portable dengan layer datar, biasanya dipakai para manajer / untuk presentasi karena sifatnya yang mobile (p. 41-42 dan 43)

- Palm Top PC

Alat ini merupakan gabungan dari sifat PDA dengan segala kapasitasnya dan LAP TOP dengan segala "mobile" nya (p. 37, 39, 40, 41).

- Wriswatch PDA

Suatu PDA mini kira-kira sebesar jam tangan dengan kapasitas laptop (p. 39-40)

- Server

Server merupakan alat untuk melakukan proses (CPU) yang dapat dihubungkan dengan computer online (p. 41-42). 


\section{- Email}

Email adalah suatu alat pengirim dan penerima berita (informasi) yang sifatnya tertulis (p. 48)

- Fax-mile

Fax-mile adalah suatu alat pengirim dan penerima data-data elektronik secara online dalam jaringan telekomunikasi (telkom)

- Internet

Internet adalah alat komunikasi dalam satu jaringan yang dihubungkan dengan satu server

- LAN (Local Area Network)

Adalah suatu jaringan yang menghubungkan beberapa PC dengan server dalam satu area terbatas (p. 76, 76, 78, 79, 80).

- WAN (White Area Network)

Sejenis I,,4N tetapi luas jangkauan lebih luas (p. 76-80).

- Document Data Base

Suatu PC yang dilengkapi dengan satu server yang dihubungkan dengan satu sen'er (p. 42, 66 dan 93).

\section{- Teleconference Software}

Yaitu program yang dapat menghubungkan secara visual dan audio lewat PC dengan satuserver(p. 152, 153 dan 154)

Semua peralatan di atas adalah alatalat yang dipakai dalam proses reengineering sumber daya manusia untuk mencapai tingkat cepat, cermat dan tepat serta menyenangkan.

\section{Masa depan reengineering sumber daya manusia}

Dengan adanya globalisasi dalam segala bidang teknik informasi harus canggih dan lebih canggih lagi. Hubungan satu negara dengan negara lain sudah tidak ada batas sehingga teknologi informasi khusus dalam bidang reengineering human resources harus dapat melayani kepentingan (kebutuhan) para pengguna jasa (customer) (p. 168-168 dan 170).

Hubungan satelit dengan globalisasi adalah data-data yang dikirim dan diterima dari satelit merupakan konsumsi dari stasiun bumi yang bcrada diseluruh dunia tanpa batas, 
Data-data yang biasa dipancarkan antara lain seperti data topografi, meteorologi, cuaca dan data SDA. Penggunaan data lewat komunikasi satelit ke bumi merupakan asset masa depan manajemen reengineering human resources (p. 150).

\section{Ulasan dan Kritik}

Sesuatu yang dipandang cukup menarik dab bahkan dapat dianggap sebagai Sesuatu yang baru dari Lyle M. Spencer dalam tulisannya yang berjudul Reengineering Human Resources adalah penggunaan kata Reengineering itu sendiri. Sebagaimana lazimnya penggunaan kata Reengineering itu dikenal dalam bidang teknologi, namun oleh Spencer, Reengineering dipasang dengan Human Resources dan kemudian penggabungan kedua kata ini mengindikasikan adanya upaya untuk menerapkan jasa teknologi khususnya jasa informasi dalam pemecahan masalah bisnis. Penekanan beliau pada sumber daya manusia mengindikasikan bagaimanapun canggihnya peralatan teknologi khususnya teknologi informasi meskipun dilengkapi dengan perangkat digital namun peran (role) manusia (human resources) sangat menentukan keberhasilan suatu perusahaan (organisasi). Yang cukup menarik lagi adalah yang dimaksud dengan human resources beliau di fokuskan pada perangkat lunak (software) dari teknologi tersebut. Dan yang dimaksud dengan perangkat lunak adalah kemampuan untuk menyusun program dan rencana strategik dalam pengoperasian perangkat keras (hardware) untuk mencapai output (hasil kerja) yang optimal sesuai kebutuhan, tepat, cepat, biaya ringan, hasil produk dan pelayanan yang bermutu ser-ta memberi kepuasan customer.

Yang melatarbelakangi munculnya ide reengineering human resources adalah pengamatan yang cermat dari Lyle Spencer, dimana menurut beliau sudah hampir 200 tahun lamanya setelah terjadinya revolusi industri di Inggris yang mempunyai dampak dan pengaruh yang dirasakan oleh hampir semua negara di dunia khususnya di Amerika Serikat, dimana telah terjadi kelesuan dibidang bisnis, beban tugas pekerja terlalu berat, biaya produksi semakin tinggi, dan pelayanan semakin lamban.

Termotivasi dengan kondisi scperti inilah Lyle Spencer muncul dengan idenya reengineering human resources dengan pemanfaatan teknologi informasi untuk membantu mengatasi permasalahan bisnis melalui reengineering human resources yang bertujuan pemenuhan kebutuhan customer baik dibidang mutu produk, mutu pelayanan dan harga produksi yang terjangkau serta tepat dalam waktu dan memuaskan. 
Berdasarkan hasil studi literatur orang pertama yang memunculkan ide reengineering adalah Hammer (1990) dalam tulisannya yang berjudul "reengineering work: don 'I authomate obliterate", Harvard Business Review, July - August yang kemudian disusul dengan bukunya yang berjudul "reengineering the corporation, New York, 1993, Harper Collins. Kemudian Green Gard S (1994) dalam tulisannya New Technology Is Human Resources 's Road To Reengineering, Personal Journal 32c-320). Selanjutnya Devenport T.H dan Short, J.E. (Summer 1994) yang berjudul and Business, Process, Redesign, Sloan Management Review", Vol "The New Industrial Engin eering: Information Technology. 31 No. 4.11.27. Masih banyak lagi tulisan-tulisan para pakar yang ahli di dalam bidang reengineering human resources yang mewarnai ide Lyle Spencer seperti misalnya Walker A. dengan tulisannya yang berjudul Reengineering The Human Resources Functions, 1992, January Human Resources Planning dan lain-lain.

Hasil studi ini membuktikan bahwa Lyle Spencer bukanlah orang yang pertama yang mencetuskan ide Reenginering Human Resources yang dikaitkan dengan jasa teknologi informasi dalam penyelesaian problem bisnis.

Mungkin yang dapat dipandang sebagai sesuatu yang baru dari Lyle Spencer adalah reformation (reformasi / merumuskan kembali), revision (memperbaharui visi), reinterpretation (menafsirkan kembali ide-ide yang sudah muncul sebelumnya) dengan mengedepankan contoh-contoh dari hasil temuan dan perkembangan teknologi yang paling mutakhir seperti internet dengan memanfaatkan perangkat digital LAN / WAN

Sebagai contoh ide tentang competitive advantage (keuntungan kompetitif) yang dikemukakan oleh Lyle Spencer banyak diwamai oleh tulisan Michael E. Porter (1985) yang berjudul: Competitive Advantage: Creating and Sustaining Superior Performance (New York, Free Press, 1985).

\section{Penutup}

Demikianlah studi penulis tentang kajian buku Lyle Spencer yang berjudul Reengineering Human Resources yang cukup menarik dalam uraian-uraian, perjelasan serta contoh-contoh yang sangat aktual dari temuantemuan perangkat teknologi informasi mutakhir yang hasilnya sangat mengagumkan, baik kecepatan, ketepatan dan jangkauan serta kemudahan-kemudahan yang disajikannya, sehingga dapat memberikan dampak positif bagi 
pcningkatan hasil produk, mutu pelayanan serta kepuasan bagi para pelanggan. Semoga tulisan ini dapat bermanfaat bagi pembaca.

\section{Daftar Pustaka}

Green Gard S. 1994. New Technology Is Human Resources 's Road To Reengineering, Personal Journal 32c-320

Hammer, M. 1990. Reengineering Work Don 't Automate, Obliterate, Harvard Bussiness Review; July - August.

Hammer, M. \& Champy, J. 1993. Reengineering the Corporation. New York: Harper Collings.

Lyle M. Spencer, Jr dalam tulisannya yang berjudul Reengineering Human Resources.

Devenport, T.H dan Short. J.E. 1994. "The New Industrial Engineering Information Technology and Business, Process, Redesign, Sloan Management Review", vol. 31 No. 4.11.27.

Porter, M.E. 1985. Competitive Advantage: Creating and Sustaining Superior Performance. New York: Free Press.

Walker, A. 1992. "Reengineering The Human Resources Functions Human Resources Planning, January 